\title{
Analisis perbedaan radiopasitas antara sealer berbahan dasar resin epoksi, mineral trioxide aggregate (MTA), dan biokeramik dengan menggunakan densitometer pada radiografi periapikal
}

\author{
Ghaisani Khansa', Sarianoferni ${ }^{1 *}$, Yongki Hadinata Wijaya ${ }^{2}$
}

\author{
1Departemen Radiologi, Fakultas Kedokteran Gigi Universitas Hang Tuah, Indonesia \\ 'Departemen Konservasi Gigi, Fakultas Kedokteran Gigi Universitas Hang Tuah, Indonesia
}

*Korespondensi: sarianoferni@gmail.com

Submisi: 22 April 2021; Penerimaan: 31 Agustus 2021; Publikasi online: 31 Agustus 2021

DOI: $\underline{10.24198 / j \mathrm{~kg} . \mathrm{v} 33 \mathrm{i} 2.33154}$

\begin{abstract}
ABSTRAK
Pendahuluan: Bahan pengisi saluran akar yang digunakan hingga saat ini adalah gutta percha yang dalam aplikasinya harus dikombinasikan dengan sealer saluran akar. Sealer yang baik harus memiliki skala radiopasitas yang tinggi sehingga dapat dibedakan densitasnya dengan jaringan disekitarnya, tujuannya supaya sealer dapat diidentifikasi maupun di monitor bila terjadi kerusakan pada gigi setelah dilakukan perawatan. Tujuan penelitian ini menganalisis perbedaan radiopasitas antara sealer berbahan dasar resin epoksi, sealer berbahan MTA, dan sealer berbahan dasar biokeramik pada teknik radiografi periapikal dengan menggunakan densitometer. Metode: Jenis penelitian observasional analitik dengan pendekatan cross sectional. Dua puluh tujuh sampel penelitian dibagi menjadi tiga kelompok. Kelompok I sealer berbahan dasar resin epoksi. Kelompok II sealer berbahan dasar MTA. Kelompok III sealer berbahan dasar biokeramik. Ketiga kelompok dimasukkan ke dalam cincin plastik berukuran $10 \times 1 \mathrm{~mm}$, kemudian dilakukan pengambilan gambar dengan teknik radiografi periapikal digital menggunakan dental $x$-ray yang beroperasi di $70 \mathrm{KVp}$ dan $8 \mathrm{~mA}$ dengan jarak fokus ke jarak $30 \mathrm{~cm}$ dan eksposur distandarisasi untuk 0,25 detik. Pengamatan dilakukan dengan menggunakan densitometer, data yang dihasilkan kemudian dianalisis menggunakan uji One Way ANOVA. Hasil: Hasil penelitian menunjukan bahwa dari ketiga kelompok terdapat perbedaan radiopasitas secara signifikan $(p<0,05)$. Sealer berbahan dasar resin epoksi $(12,9 \mathrm{mmAl})$ secara signifikan lebih radiopak daripada sealer berbahan dasar biokeramik $(8,04 \mathrm{mmAl})$ dan sealer berbahan dasar MTA (6,90 mmAl). Radiopasitas dipengaruhi oleh komposisi bahan kimia, media kontras anorganik, nomor atom, komposisi radiopacifier dan densitas pada sealer. Simpulan: Sealer berbahan dasar resin epoksi memiliki radiopasitas tertinggi dibandingkan dengan yang berbahan dasar MTA dan biokeramik.
\end{abstract}

Kata kunci: sealer saluran akar; radiografi; periapikal

\begin{abstract}
Analysis of radiopacity differences between sealers based on epoxy resin, mineral trioxide aggregate (MTA), and bioceramics on periapical radiographs using a densitometer
\end{abstract}

\section{ABSTRACT}

Introduction: Nowadays, gutta-percha is widely used as the root canal filling material. However, in its application, it must be combined with a root canal sealer. A good sealer must have a high radiopacity scale value to distinguish its density from the surrounding tissue. In addition, the sealer must be able to be identified and monitored concerning the damage to the teeth after treatment. The purpose of this study was to analyse the radiopacity differences between sealers based on epoxy resin, mineral trioxide aggregate (MTA), and bioceramics on periapical radiographs using a densitometer. Methods: Jenis penelitian observasional analitik dengan pendekatan cross sectional.Twenty-seven study samples were divided into three groups. Group I consisted of an epoxy resin-based resin. Group II consisted of an MTA-based sealer. Group III consisted of a bioceramic-based sealer. The three groups were put in a $10 \times 1 \mathrm{~mm}$ plastic ring. The radiographic images were taken using digital periapical radiography using dental x-rays operating at $70 \mathrm{KVp}$ and $8 \mathrm{~mA}$ with a focal distance of $30 \mathrm{~cm}$ and exposure standardised to 0.25 seconds. Observations were performed using a densitometer, and the resulting data were then analysed using the One-Way ANOVA test. Results: The results showed that there was a significant difference in radiopacity $(p<0.05)$. Epoxy resin-based sealers (12.9 mmAl) were significantly more radiopaque than bioceramic-based sealers (8.04 mmAl) and MTA-based sealers (6.90 mmAl). Radiopacity is influenced by chemical composition, inorganic contrast medium, atomic number, radiopacifier composition and sealer density. Conclusions: Epoxy resin-based sealers have the highest radiopacity compared to MTA and bioceramic-based sealers.

Keywords: canal sealer; radiography; periapical 


\section{PENDAHULUAN}

Kesehatan gigi dan mulut merupakan bagian integral dari kesehatan secara keseluruhan yang dapat mempengaruhi kualitas hidup manusia. ${ }^{1}$ Diagnosis pada beberapa penyakit terutama pada gigi dan mulut bergantung pada pemeriksaan radiografi. Sebuah radiograf harus dapat memberikan informasi yang jelas dalam upaya membantu menegakkan diagnosis. ${ }^{2}$

Perawatan saluran akar merupakan salah satu langkah perawatan dalam ilmu endodontik. Tahapan penting dalam perawatan saluran akar adalah pengisian saluran akar yang aplikasinya harus dikombinasikan dengan sealer. Salah satu syarat sealer adalah bersifat radiopak. ${ }^{3,4}$ Sealer harus cukup radiopak untuk memungkinkan perbedaan bahan pengisi saluran akar dari struktur anatomis yang berdekatan seperti tulang dan gigi. ${ }^{5}$ Bahan pengisi saluran akar harus memiliki cukup radiopasitas untuk melihat dengan jelas kehadiran dari bahan pengisi saluran akar, sejauh mana dan kondensasi yang jelas. Menurut ISO 6876:2012, tingkat radiopasitas bahan pengisi saluran akar harus setara atau lebih dari $3 \mathrm{~mm}$ ketebalan aluminium. ${ }^{6}$ Aluminium Step wedge merupakan sebuah blok persegi panjang yang terbuat dari aluminium. (ISO) 4049/2019 menyatakan bahwa aluminium memiliki radiopasitas yang setara dengan dentin. Material dengan tingkat radiopasitas $1 \mathrm{~mm}$ aluminium, memiliki radiopasitas yang setara dengan dentin. ${ }^{7}$ Sebuah sealer yang menunjukkan radiopasitas di atas $3 \mathrm{~mm}$ aluminium dianggap ideal untuk diferensiasi, misalnya dari pengisian saluran akar lateral, pengisian berlebih, atau struktur anatomis. ${ }^{8}$

Bahan pengisi saluran akar sangat berkontribusi pada radiopasitas dari perawatan saluran akar untuk visualisasi dan evaluasi pengisian kanal lateral dan ramifikasi apikal. ${ }^{6}$ Radiografi adalah metode yang memanfaatkan kemampuan radiasi untuk menembus bahan sehingga menghasilkan gambaran dua dimensi suatu objek pada film. Objek yang bersifat padat akan tampak sebagai gambaran putih (radiopak), hal ini disebabkan karena berkas cahaya dari sinar-X diserap saat melewati objek tersebut. ${ }^{9}$

Pengukuran densitas pada gambaran radiografi konvensional salah satunya dapat menggunakan alat densitometer. ${ }^{6}$ Densitometer dapat menentukan kepadatan sampel yang ditempatkan antara sumber cahaya dan sel fotolistrik, sehingga densitas sebuah radiografi dapat diukur. Semakin kecil nilai Optical Density pada densitometer (mendekati 0) maka densitasnya semakin rendah atau lebih radiopak. ${ }^{10,11}$ Semakin radiopak suatu sealer maka semakin kecil gelembung udara yang terjebak dari hasil pengisian. ${ }^{4}$ Penampakan radiografi sealer yang radiopak juga membantu memperlihatkan gambaran yang padat tanpa terdapat kelebihan maupun kekurangan. ${ }^{12}$

Sealer yang digunakan dalam perawatan endodontik dibagi menjadi beberapa bahan dasar antara lain sealer berbahan dasar seng oksida eugenol, kalsium hidroksida, ionomer kaca, resin epoksi, Mineral Trioxide Aggregate (MTA), dan Biokeramik. ${ }^{13,14}$ Radiopasitas suatu sealer dipengaruhi oleh komposisi bahan kimia, media kontras anorganik, nomor atom, komposisi radiopacifier dan densitas pada sealer. Sealer berbahan dasar resin epoksi merupakan sealer saluran akar yang memiliki sifat radiopak, kelarutan rendah, penyusutan kecil, memiliki sifat antibakteri, dan toksisitas rendah. ${ }^{4}$ Sealer berbahan dasar MTA adalah bahan biokompatibel dengan berbagai aplikasi klinis dalam perawatan saluran akar. MTA tidak hanya memberikan sifat mekanis seperti sealing ability yang baik, tetapi juga memiliki tingkat radiopasitas yang tinggi karena mengandung bismut oksida dalam komposisinya. ${ }^{15}$ Biokeramik adalah bahan tambahan yang relatif baru dan berpotensi menjanjikan untuk kelompok bahan yang tersedia untuk pengisian ujung akar. ${ }^{16}$

Beberapa sifat komposisi baik fisik-kimia penting dari bahan pengisi saluran akar sealer dapat dipertimbangkan untuk mengevaluasi kriteria tingkatan radiopasitas. Kalsium sudah lama digunakan sebagai filler dalam baberapa sealer komersial dan dapat mempengaruhi radiopasitas yang tinggi, selain kalsium, bismuth oksida, barium, stronsium, atau zirkonium oksida, dan senyawa logam berat/ atom berat lainnya seperti Ytterbium(III) Fluoride, yang dapat mengabsorbsi sinar-X juga mempengaruhi gambaran yang radiopak pada radiograf. ${ }^{17}$ Radiopacifier sealer berbahan dasar resin epoksi yang berkontribusi dalam tingkat radiopasitasnya adalah kalsium tungstat dan zirkonium oksida. Zirkonium oksida dapat ditambahkan ke material bahan kedokteran 
gigi supaya membuat sealer tersebut cukup radiopak. $^{18}$

Tiga bahan dasar sealer yaitu sealer berbahan dasar resin epoksi, sealer berbahan dasar MTA, dan sealer berbahan dasar biokeramik banyak digunakan oleh klinisi. ${ }^{4}$ Komposisi dari ketiga bahan dasar sealer tersebut beragam dan memiliki tingkat radiopasitas yang berbeda, sehingga tujuan penelitian adalah menganalisis perbedaan radiopasitas antara sealer berbahan dasar resin epoksi, sealer berbahan MTA, dan sealer berbahan dasar biokeramik pada teknik radiografi periapikal dengan menggunakan densitometer.

\section{METODE}

Penelitian ini merupakan jenis penelitian observasional analitik dengan pendekatan cross sectional. ${ }^{19}$ Unit eksperimen pada penelitian ini terdiri dari 9 sealer berbahan dasar resin epoksi, 9 sealer berbahan dasar MTA, dan 9 sealer berbahan dasar biokeramik. Teknik sampling pada penelitian ini yaitu dengan cara total sampling karena jumlah sampel sama dengan jumlah populasi. ${ }^{20}$ Penelitian ini dilaksanakan pada bulan November 2020 di Badan Pengawasan Fasilitas Kesehatan (BPFK) Surabaya untuk pengukuran densitasnya dan laboratorium radiologi Universitas Hang Tuah Surabaya untuk pengambilan foto radiograf.

Tahapan penelitian pertama adalah pengisian kelompok pertama sealer berbahan dasar resin epoksi diaduk antara pasta $A$ dan pasta B. Perbandingan antara pasta $A$ dan pasta B adalah 1:1. Pasta A dan pasta B diaduk menggunakan agate spatel di atas paper pad dan diaduk hingga diperoleh konsistensi yang kental dan homogen lalu dimasukkan ke dalam cincin plastik 10 x $1 \mathrm{~mm}$ menggunakan plastis instrumen. Kelompok kedua yaitu sealer berbahan dasar MTA yaitu MTA. Sealer langsung dimasukkan ke dalam cincin plastik $10 \times 1 \mathrm{~mm}$ di atas paper pad karena sudah menyatu antara basis dan katalisnya dalam satu syringe lalu diratakan menggunakan plastis instrumen. Kelompok ketiga yaitu sealer berbahan dasar biokeramik. Sealer langsung dimasukkan ke dalam cincin plastik $10 \times 1 \mathrm{~mm}$ di atas paper pad karena sudah menyatu antara basis dan katalis dalam syringe lalu diratakan menggunakan plastis instrumen.
Pembuatan radiografi periapikal dilakukan dengan menggunakan teknik kesejajaran. Menggunakan dental $X$-ray bermerek villa, tipe endos ACP, dengan nomor SN 31091126 (Gambar 1). Subyek penelitian dan Aluminium Stepwedge dilakukan radiografi teknik periapikal satu persatusatu berdasarkan masing-masing kelompok sampel. Dental X-Ray beroperasi di $70 \mathrm{KVp}$ dan 8 $\mathrm{mA}$ dengan fokus ke target jarak $30 \mathrm{~cm}$ (ANSI/ADA 2000) digunakan pembuatan radiografi. Eksposur distandarisasi untuk 0,25 detik. Nilai densitas radiografi diukur menggunakan alat densitometer. Alat densitometer yang digunakan Densitometer RMI X-Rite 2-331 yang dapat dibawa secara portabel dan memiliki tingkat akurasi yang tinggi.

Pengukuran densitas dilakukan secara konvensional dengan alat densitometer (Gambar 2). Nilai Optical Density pada densitometer berkisar antara 0 hingga 3. Semakin terang atau putihnya gambaran radiografi suatu objek menunjukkan semakin radiopaknya objek tersebut

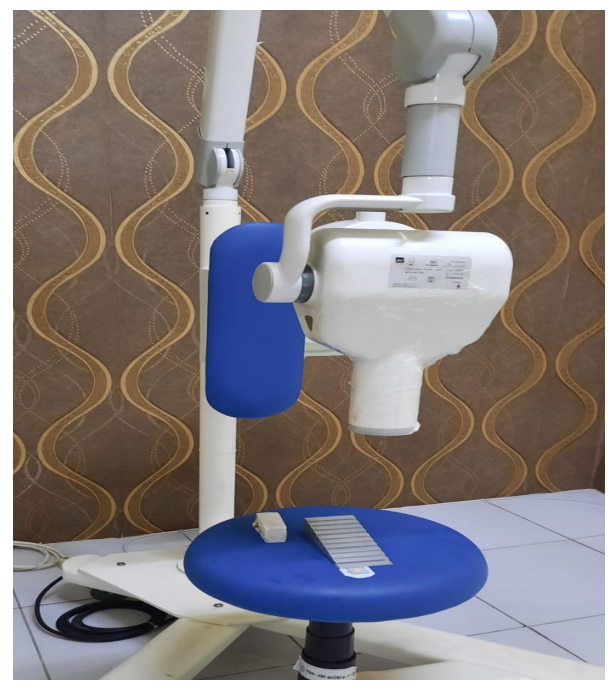

Gambar 1. Dental X-Ray Villa Endos.(Sumber: Dokumentasi pribadi)

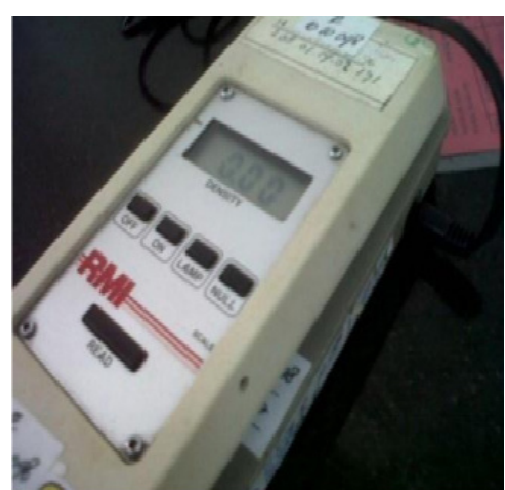

Gambar 2. Densitometer RMI X-Rite 2-331. (Sumber: Dokumentasi pribadi) 
dan sebaliknya semakin gelap atau hitamnya suatu gambaran radiografi maka menunjukkan semakin radiolusennya objek tersebut sehingga densitas objek tersebut kurang padat. Penelitian ini menggunakan uji one way anova untuk menganalisis perbedaan radiopasitas antara sealer berbahan dasar resin epoksi, sealer berbahan dasar Mineral Trioxide Aggregate (MTA), dan sealer berbahan dasar biokeramik.

\section{HASIL}

Radiografi diambil dari ketiga kelompok sampel setelah sampel sealer telah setting sempurna lalu diberikan paparan radiografi dengan Dental X-Ray yang beroperasi di $70 \mathrm{KVp}$ dan $8 \mathrm{~mA}$ dengan jarak fokus ke jarak $30 \mathrm{~cm}$ dan eksposur distandarisasi untuk 0,25 detik. Prosedur pengukuan nilai radiopasitas ketiga kelompok sealer dilakukan dengan menggunakan densitometer, (Gambar 3) memperlihatkan radiograf sampel sealer berbahan dasar resin epoksi, (Gambar 4) memperlihatkan radiograf sampel sealer berbahan dasar biokeramik, dan (Gambar 5) memperlihatkan radiograf sampel sealer berbahan dasar MTA. Masing-masing kelompok diberi perbandingan radiopasitas dengan penempatan ketebalan Aluminium stepwedge $0,5 \mathrm{mmAl}$ dan $1 \mathrm{mmAl}$.
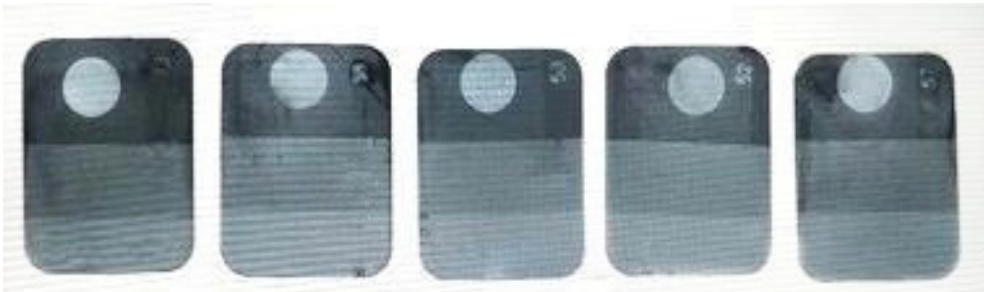

Gambar 3. Hasil radiografi sampel sealer berbahan dasar resin epoksi. Area yang diukur adalah bulatan yang berisi tiaptiap bahan dasar sealer berbahan dasar resin epoksi.
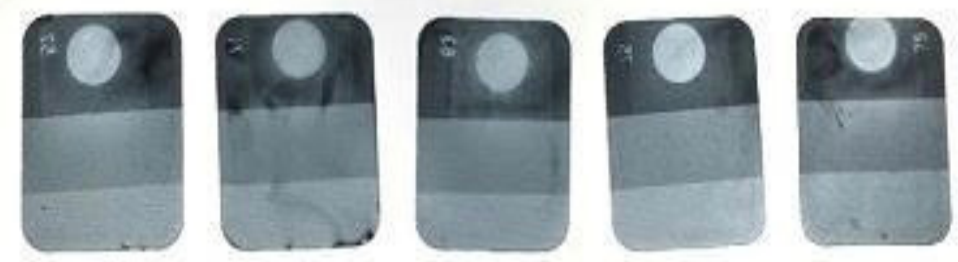

Gambar 4. Hasil radiografi sampel sealer berbahan dasar biokeramik. Area yang diukur adalah bulatan yang berisi tiap-tiap bahan dasar sealer berbahan dasar biokeramik.

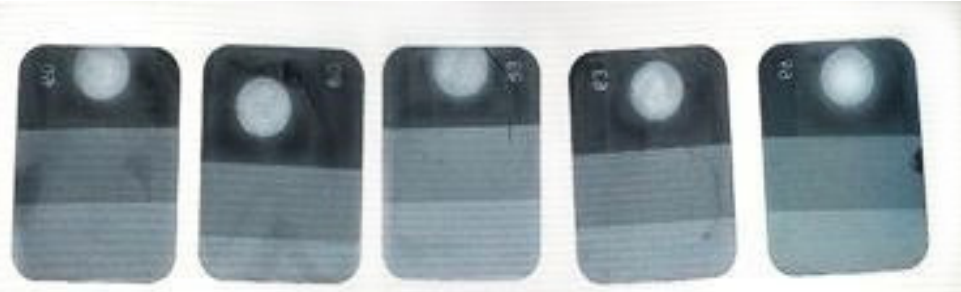

Gambar 5. Hasil radiografi sampel sealer berbahan dasar MTA. Area yang diukur adalah bulatan yang berisi tiap-tiap bahan dasar sealer berbahan dasar MTA.

Pengamatan dilakukan dengan teknik radiografi periapikal dengan menggunakan densitometer. Hasil radiopasitas dievaluasi dari skor OD (Optical Density) yang berkisar antara 0 (terlalu radiopak) - 3 (terlalu radiolusen). Dari penelitian yang telah dilakukan terhadap 27 sampel sealer (masing-masing kelompok 9 sampel) (Tabel 1).
Tabel 1. Nilai Optical Density dan pengukuran dalam milimeter aluminium tiap sampel penelitian

\begin{tabular}{lcc}
\hline \multicolumn{1}{c}{ Sampel } & $\begin{array}{c}\text { Optical } \\
\text { density }\end{array}$ & mmAl \\
\hline Sealer berbahan dasar resin epoksi & 0.256 & 12.9 \\
Sealer berbahan dasar biokeramik & 0.754 & 8.04 \\
Sealer berbahan dasar MTA & 0.838 & 6.90 \\
\hline
\end{tabular}


Tabel 1 di atas, dari total 27 sampel terdapat 9 sampel sealer berbahan dasar resin epoksi, 9 sampel sealer berbahan dasar biokeramik, dan 9 sampel sealer berbahan dasar MTA. Sealer berbahan dasar resin epoksi mempunyai nilai ratarata optical density sebesar 0,26 atau setara dengan $(12,9 \mathrm{mmAl})$. Sealer berbahan dasar biokeramik mempunyai nilai rata-rata optical density sebesar 0,75 atau setara dengan $(8,04 \mathrm{mmAl})$. Sealer berbahan dasar MTA mempunyai nilai rata-rata optical density sebesar 0,84 atau setara dengan $(6,90 \mathrm{mmAl})$.

Hasil dari Tabel 1 dapat disimpulkan bahwa tingkat radiopasitas paling tinggi dimiliki oleh sealer berbahan dasar resin epoksi diikuti oleh sealer berbahan dasar biokeramik dan sealer berbahan dasar MTA. Hasil uji Shapiro-wilk dan Levene test berdistribusi normal dan homogen, karena syarat terpenuhi dilanjutkan dengan uji statistik parametrik menggunakan uji One Way ANOVA

Tabel 2. Hasil uji One Way Anova optical density kelompok sampel

\begin{tabular}{|c|c|c|c|}
\hline & df & $F$ & Sig. \\
\hline Between groups & 2 & \multirow{2}{*}{4218.442} & \multirow{2}{*}{$<, 001$} \\
\hline Within groups & 24 & & \\
\hline Total & 26 & & \\
\hline
\end{tabular}

karena penelitian ini termasuk uji komparasi dengan sampel $>2$ bebas.

Hasil uji Anova (Tabel 2), diketahui bahwa terdapat perbedaan radiopasitas sealer yang bermakna, karena signifikansi lebih kecil dari 0,05 . Selanjutnya, dilakukan uji Least Significant Difference (LSD) untuk mengetahui pada kelompok sampel mana saja yang terdapat perbedaan radiopasitas sealer secara bermakna.

Uji LSD adalah pengujian perbandingan jamak untuk menentukan apakah nilai rata-rata berbeda secara signifikan dalam jumlah analisis varian. Untuk menguji apakah terdapat perbedaan rata-rata ketiga sealer tersebut, maka harus didapatkan nilai signifikansi hasil output SPSS lebih besar atau lebih kecil dari 0,05.

Hasil uji LSD pada Tabel 3 didapatkan nilai signifikansi $<0,001$ pada perbandingan antara ketiga kelompok sampel. Nilai signifikansi tersebut lebih kecil dari 0,05 , sehingga dapat dikatakan terdapat perbedaan radiopasitas sealer yang bermakna pada semua kelompok sampel, yaitu kelompok sealer berbahan dasar resin epoksi, biokeramik, dan MTA. Perbedaan paling tinggi terlihat pada kelompok sampel sealer berbahan dasar resin epoksi dan sealer berbahan dasar MTA.

Tabel 3. Hasil uji LSD

\begin{tabular}{llcc}
\hline \multicolumn{1}{c}{ Sampel (I) } & \multicolumn{1}{c}{ Sampel $(\mathrm{J})$} & Mean difference & Sig. \\
\hline Sealer berbahan dasar resin epoksi & Sealer berbahan dasar biokeramik & $-.495333\left(^{*}\right)$ & $<0,001$ \\
& Sealer berbahan dasar MTA & $-.579111\left(^{*}\right)$ & $<0,001$ \\
Sealer berbahan dasar biokeramik & Sealer berbahan dasar resin epoksi & .495333 & $<0,001$ \\
Sampel & Optical Density & $\mathrm{mmAl}$ & $<0,001$ \\
Sealer berbahan dasar MTA & Sealer berbahan dasar resin epoksi & $.579111\left(^{*}\right)$ & $<0,001$ \\
& Sealer berbahan dasar biokeramik & .083778 & $<0,001$ \\
\hline
\end{tabular}

$\left({ }^{*}\right)=$ menunjukkan perbedaan yang bermakna

\section{PEMBAHASAN}

Gambaran yang radiopak dalam radiograf memerlukan partikel logam berat juga dengan nomor atom tinggi yang digabungkan ke dalam material. Terdapat unsur-unsur dalam periode keenam atau lebih tinggi dari tabel periodik, yang telah terbukti secara umum berguna sebagai senyawa radiopak. Suatu material dengan nomor atom yang besar menyebabkan radiasi yang terserap akan lebih banyak daripada radiasi yang dihamburkan sehingga material tersebut memiliki gambaran yang lebih radiopak. ${ }^{17}$
Semakin padatnya material yang diukur, maka sinar-X yang dapat menembus akan semakin sedikit, akibatnya intensitas sinar- $X$ yang sampai ke film semakin kecil. Semakin kecil intensitas sinar- $X$ yang sampai ke film maka nilai OD akan semakin kecil/ semakin radiopak. Sebaliknya, jika material yang diukur kurang padat, maka sinar- $X$ yang dapat menembus akan semakin banyak, akibatnya intensitas sinar-X yang sampai ke film semakin besar. Semakin besar intensitas sinar- $X$ yang sampai ke film maka nilai OD akan semakin besar/ semakin radiolusen. 
Radiopasitas sealer berbahan dasar resin epoksi dengan menggunakan densitometer pada radiografi periapikal

Sealer berbahan dasar resin epoksi memiliki komposisi sebagai berikut Diepoxide, Kalsium tungstat, Zirkonium oksida, Aerosil, Pigment, 1-adamantane amine, $\quad N, \quad$ N'-dibenzyl-5-oxanonandiamine-1,9, Diamine, Calcium tungstate, Zirconium oxide, Aerosil, Silicone oil. Sealer ini memiliki $\mathrm{pH} 7,81$ sampai $7,17 .{ }^{21}$

Radiopacifier sealer berbahan dasar resin epoksi yang berkontribusi adalah kalsium tungstat dan zirkonium oksida. Zirkonium oksida dapat ditambahkan ke material bahan kedokteran gigi supaya membuat sealer tersebut radiopak. ${ }^{22}$ Penelitian terdahulu yang membandingkan bahan radiopacifier dari zirkonium oksida dan bismut oksida ${ }^{23}$ menunjukkan bahwa zirkonium oksida adalah bahan yang dapat meningkatkan radiopasitas dan juga dapat meningkatkan sifat fisik seperti kekuatan tekan, dan memberikan respon biologis yang lebih baik daripada bismut oksida.

Komposisi dari sealer berbahan dasar resin epoksi digunakan kalsium tungstat dengan ukuran partikel rata-rata $8 \mu \mathrm{m}$ dan zirkonium oksida ratarata ukuran partikel $1,5 \mu \mathrm{m}$ yang digiling halus. ${ }^{17}$ Nomor atom dari radiopacifier sealer berbahan dasar resin epoksi yang terdiri dari zirkonium oksida memiliki nomor atom 40 dan kalsium tungstat memiliki nomor atom 75. Penelitian terdahulu ini dapat menjelaskan fakta bahwa sealer berbahan dasar resin epoksi menghadirkan tingkat radiopasitas yang lebih tinggi karena mengandung zirkonium oksida dan kalsium tungstat sebagai radiopacifier nya. ${ }^{24}$

Berdasarkan penelitian ini bahan radiopacifier sealer berbahan dasar resin epoksi merupakan bahan sealer yang memiliki radiopasitas tertinggi dibandingkan dengan sealer berbahan dasar MTA dan sealer berbahan dasar biokeramik yaitu optical density sebesar 0.25922 atau setara dengan 12,9 $\mathrm{mmAl}$ karena radiopacifier yang terkandung dalam sealer berbahan dasar resin epoksi yaitu zirkonium oksida dan kalsium tungstat memiliki nomor atom tinggi, sifat psikomekanis yang lebih baik, komposisi radiopacifier yang lebih besar, serta densitas yang lebih tinggi daripada dua sampel lainnya.

\section{Radiopasitas sealer MTA dengan menggunakan densitometer pada radiografi periapikal}

Sealer berbahan dasar MTA memilik komposisi $80 \%$ semen portland dan $20 \%$ bismut oksida. ${ }^{18}$ Bismut oksida $\left(\mathrm{Bi}_{2} \mathrm{O}_{3}\right)$ yang ditambahkan pada suatu material kedokteran gigi dapat meningkatkan nilai radiopasitas hingga $6-8 \mathrm{~mm}$ Aluminium. ${ }^{22}$ Bismut oksida memiliki nomor atom yaitu 83, dua kali lebih besar dari nomor atom yang dimiliki oleh zirkonium oksida yaitu 40 . Bagaimanapun, penelitian sebelumnya pernah meneliti bahwa tingkat radiopasitas juga dapat dipengaruhi oleh variasi-variasi kecil yang terdapat dalam komposisi dari beberapa sealer, seperti konsentrasi yang lebih tinggi dari besi oksida, dan juga komposisi radiopacifier. ${ }^{25}$

Bismut oksida yang ditambahkan sebagai radiopacifier di beberapa sealer berbahan dasar MTA, dapat berpartisipasi dalam proses hidrasi partike ${ }^{25}$ serta lama kelamaan dapat menyebabkan perubahan warna gigi atau diskolorasi, ${ }^{18}$ terutama jika berkontak dengan sodium hipoklorit. ${ }^{26}$ Bismut oksida juga menunjukkan sifat toksik yang pada tingkat tertentu mirip dengan tetangganya dalam tabel periodik. ${ }^{27}$ Oleh karena adanya sifat toksikyang terkandung bismut oksida dalam MTA, dilakukan penelitian oleh Cutajar mengenai radiopacifier alternatif yang disarankan untuk menggantikan bismut oksida seperti material dengan massa molekul relatif tinggi yaitu penambahan zirkonium oksida yang dapat menghasilkan nilai radiopasitas lebih dari $3 \mathrm{mmAl}^{28}$

Nomor atom yang dimiliki oleh bismut oksida lebih besar dua kali lipat daripada zirkonium oksida, setidaknya butuh $40 \%$ berat bubuk zirkonium oksida yang diperlukan untuk mencapai radiopasitas yang sebanding atau lebih dari sealer berbahan dasar MTA. Diketahui dalam penelitian Cutajar yang meneliti mengenai Penggantian Radiopacifier dalam MTA; Karakterisasi dan Penentuan Sifat Fisik, dimana dalam penelitian tersebut radiopacifier bismut oksida digantikan dengan zirkonium oksida $30 \%$ dengan perbandingan water/powder dengan rasio 3/10 menghasilkan radiopasitas yang adekuat dan lebih baik. Hal ini dapat diasumsikan dengan tepat bahwa proporsi water/powder yang lebih rendah berkontribusi pada peningkatan radiopasitas bahan yang dihasilkan. ${ }^{29}$ 
Tabel 1 dapat dilihat bahwa mean dari optical density sealer berbahan dasar MTA adalah sebesar 0,83833 atau setara dengan (6,90 $\mathrm{mmAl}$ ). Komposisi radiopacifier pada sealer MTA memberikan radiopasitas melebihi batas minimal yang telah ditetapkan oleh ISO yaitu tingkat radiopasitas bahan pengisi saluran akar harus setara atau lebih dari $3 \mathrm{~mm}$ ketebalan aluminium.

\section{Radiopasitas sealer berbahan dasar biokeramik dengan menggunakan densitometer pada radiografi periapikal}

Sealer berbahan dasar resin epoksi dan sealer berbahan dasar biokeramik memiliki agen radiopacifier yang sama yaitu zirkonium oksida, tetapi pada sealer berbahan dasar resin epoksi memiliki agen radiopacifier tambahan yaitu kalsium tungstat. ${ }^{4}$ Komposisi yang terkandung dari sealer berbahan dasar biokeramik adalah kalsium silikat, zirkonium oksida, dan agen pengental. Studi yang telah dilakukan oleh Gandolfi, menunjukkan bahwa kandungan kalsium silikat yang terdapat dalam sealer hanya dapat mencapai radiopasitas yang adekuat dengan menambahkan komposisi lain yaitu $30 \%$ seng oksida, ${ }^{23}$ dan penting untuk memperhatikan nomor atom yang tinggi. ${ }^{22}$

Terdapat bukti penelitian yang dilakukan oleh Camilleri bahwa dengan penambahan zirkonium oksida ke dalam sealer yang mengandung kalsium silikat memberikan material tersebut sifat psikomekanis yang cocok untuk digunakan sebagai material pengisi saluran akar. ${ }^{28}$ Sealer berbahan dasar biokeramik merupakan sealer berbasis kalsium silikat yang berasosiasi dengan zirkonium oksida. Penambahan zirkonium oksida $30 \%$ dalam sealer ini menginduksi proliferasi fibroblas dan mempercepat regresi reaksi inflamasi ketika dibandingkan dengan MTA. ${ }^{27}$

Penambahan $30 \%$ agen radiopacifier yaitu zirkonium oksida dapat memberikan radiopasitas yang lebih tinggi dari sealer MTA. Penelitian yang dilakukan oleh Cutajar tahun 2011 yang meneliti MTA yang diganti komposisi radiopacifier nya dengan penambahan $30 \%$ zirkonium oksida yang dengan proporsi water/powder 3/10 menghasilkan kombinasi sifat yang optimum. Bahan ini menunjukkan radiopasitas, kekuatan tekan, waktu setting, kelarutan, dan penyerapan yang lebih baik daripada sealer berbahan dasar MTA dengan radiopacifier bismut oksida. Baik mikroskopik dan evaluasi porositas dari percobaan kelarutan dan penyerapan menunjukkan derajat porositas yang terdiri dari pori-pori kapiler dan kedap lubang udara. ${ }^{28}$ Teori tersebut dapat dibuktikan pada Tabel 2 bahwa terdapat perbedaan yang bermakna antara radiopasitas sealer berbahan dasar resin epoksi, biokeramik, dan MTA, dimana sealer berbahan dasar biokeramik menempati urutan tinggi radiopasitas kedua yaitu optical density sebesar 0.754565 atau setara dengan $8.04 \mathrm{mmAl}$.

\section{SIMPULAN}

Terdapat perbedaan radiopasitas yang bermakna antara sealer berbahan dasar resin epoksi, sealer berbahan dasar MTA, dan sealer berbahan dasar biokeramik dengan menggunakan densitometer pada radiografi periapikal. Sealer berbahan dasar resin epoksi mempunyai nilai rata-rata optical density sebesar 0,26 atau setara dengan (12,9 mmAl) dan menempati urutan radiopasitas tertinggi pertama.Sealer berbahan dasar biokeramik mempunyai nilai rata-rata optical density sebesar 0,75 atau setara dengan (8,04 $\mathrm{mmAl}$ ) dan menempati urutan radiopasitas tertinggi kedua.Sealer berbahan dasar MTA mempunyai nilai rata-rata optical density sebesar 0,84 atau setara dengan $(6,90 \mathrm{mmAl})$ dan menempati urutan radiopasitas tertinggi ketiga.

\section{DAFTAR PUSTAKA}

1. Kemenkes RI. Profil Kesehatan Indonesia. Jakarta: Kementerian Kesehatan Republik Indonesia; 2018. h. 23-243

2. Whaites E, Drage N. Essentials of Dental Radiography and Radiology. $5^{\text {th }}$ ed. London: Churcill Livingstone Elsevier; 2013. p. 171-91.

3. Grossman LI, Seymour O, Carlos E. IImu Endodontik Dalam Praktek. $11^{\text {th }}$ ed. Jakarta: EGC; 2013. p. 196, 247-64.

4. Hajir R, Iswani R, Widyawati. Perbedaan radiopasitas antara bahan obturasi sealer berbahan dasar kalsium hidroksida dan epoksi rasin dengan Teknik Radiografi Cone Beam Computed Tomography (CBCT). J B-Dent 2018;5(1):49-55. DOI: https://doi. org/10.33854/JBDjbd.138

5. Tanomaru-Filho $M$, Bosso $R$, Viapiana $R$, Guerreiro-Tanomaru JM. Radiopacity and flow 
of different endodontic sealers. Acta Odontol Latinoam. 2013;26(2):121-5.

6. Bansal R, Jain A. Overview on the current antibiotic containing agents used in endodontics. N Am J Med Sci. 2014;6(8):3518. DOI: $10.4103 / 1947-2714.139277$

7. Pekkan G. Radiopacity of Dental Materials: An Overview. Avicenna J Dent Res. 2016;892: 1-5. DOI: $10.17795 / a j d r-36847$

8. Vidotto APM, Cunha RS, Zeferino EG, Rocha DGP, Martin ASD, Eduardo Carlos, et al. Comparison of MTA fillapex radiopacity with five root canal sealers. Rev Odonto 2011;57(8):404-9.

9. White SC, Pharoah MJ. Oral Radiology: Principles and Interpretation. $7^{\text {th }}$ ed. St. Louis: Mosby-Elsevier; 2014. p. 171-95

10. Harish M. Perbedaan densitas tulang alveolar regio molar pertama akibat aktivitas membarong reog ponorogo berdasarkan radiografi periapikal. [Skripsi]. Fakultas Kedokteran Gigi; Univ Jember; 2015. h. 18-20.

11. Wijayanti LA, Hidayat B, Suhardjo. Pengolahan citra radiograf periapikal pada deteksi penyakit granuloma menggunakan metode discrete wavelet transform \& principal component analysis berbasis android. E-Proceeding of engineering. 2017;4(1):547-54.

12. Poedyaningrum F. Perbandingan kebocoran mikro sepertiga apeks pada pengisian saluran akar dengan semen resin epoksi dan MTA. [Skripsi]. Fakultas Kedokteran Gigi; Universitas Indonesia; 2013. p. 17, 21-4.

13. Hubbe KL, Oliveira DKV, Coelho BS, and Baratto-Filho F. AH Plus extrusion into periapical tissue. Literature review of main related properties and report of clinical cases. Mater Scie 2017;13(4);280-8. DOI: 10.21726/ rsbo.v13i4.352

14. Enggardipta RA, Untara RTE, Santosa P, Kartikaningtyas AT, Widyastuti A, Ratih DN. Apical sealing ability of chitosan nanoparticles in epoxy-resin-based endodontic sealer. 2019; 5(2): 69-74. DOI: 10.22146/majkedgiind.40995

15. Kharouf N, Zghal J, Addiego F, Gabelout M, Jmal H, Haikel Y, Bahlouli N, Ball V. Tannic acid speeds up the setting of mineral trioxide aggregate cements and improves its surface and bulk properties. J Colloid Interface Sci. 2021;589:318-26. DOI: 10.1016/j. icis. 2020.12.115.

16. Garg, N. and Garg.A. Textbook of Operative Dentistry. New Delhi. $3^{\text {rd }}$ ed. Jaypee Brothers Medical Publishers; 2014. p. 282-301.

17. Collares FM, Klein M, Santos PD, Portella FF, Ogliari F, Leitune VC, Samuel SM. Influence of radiopaque fillers on physicochemical properties of a model epoxy resin-based root canal sealer. J Appl Oral Sci. 2013;21(6):5339. DOI: $10.1590 / 1679-775720130334$.

18. Guerreiro-Tanomaru JM, Trindade-Junior A, Costa BC, da Silva GF, Drullis Cifali L, Basso Bernardi MI, Tanomaru-Filho M. Effect of zirconium oxide and zinc oxide nanoparticles on physicochemical properties and antibiofilm activity of a calcium silicate-based material. Sci World J. 2014;2014:975213. DOI: 10.1155/2014/975213.

19. Notoatmodjo S. Metodologi Penelitian Kesehatan. Cetakan ketiga. Jakarta: Rineka Cipta; 2018. h. 307

20. Sarjono, Haryadi dan Winda Julianita, SPSS VS Lisrel Sebuah Pengantar, Aplikasi Untuk Riset, Jakarta: Salemba Empat, 2013. h. 282

21. Cohen S, Hargreaves K. Cohen's Pathways of The Pulp. $12^{\text {th }}$ Ed. St. Louis: Mosby Elsevier; 2021. p. 1092-7, 1106.

22. Camilleri J, Cutajar A, Mallia B. Hydration characteristics of zirconium oxide replaced Portland cement for use as a root-end filling material. Dent Mater. 2011;27(8):845-54. DOI: 10.1016/j.dental.2011.04.011.

23. Siboni $F$, Taddei $P$, Zamparini $F$, Prati $C$, Gandolfi MG. Properties of BioRoot RCS, a tricalcium silicate endodontic sealer modified with povidone and polycarboxylate. Int Endod J. 2017; 50 Suppl 2: e120-36. DOI: 10.1111/ iej.12856.

24. Candeiro DM, George T, Correia C. Evaluation of Radiopacity , pH , Release of Calcium lons, and Flow of a Bioceramic Root Canal Sealer. Basic Researh Technology. 2012;38(6):842-5. DOI: 10.1016/j.joen.2012.02.029.

25. Aguilar FG, Garcia Lda F, Rossetto HL, Pardini LC, Pires-de-Souza Fde C. Radiopacity evaluation of calcium aluminate cement containing different radiopacifying agents. J Endod. 2011;37(1):67-71. DOI: 10.1016/j. joen.2010.10.001.

26. Camilleri J. Color stability of white mineral 
trioxide aggregate in contact with hypochlorite solution. J Endod. 2014;40(3):436-40. DOI: 10.1016/j.joen.2013.09.040.

27. Silva EJ, Perez R, Valentim RM, Belladonna FG, De-Deus GA, Lima IC, Neves AA. Dissolution, dislocation and dimensional changes of endodontic sealers after a solubility challenge: a micro-CT approach. Int Endod J. 2017; 50(4):407-14. DOI: 10.1111/iej.12636.

28. Cutajar A, Mallia B, Abela S, Camilleri J.
Replacement of radiopacifier in mineral trioxide aggregate; characterization and determination of physical properties. Dent Mater. 2011;27(9):879-91. DOI: 10.1016/j. dental.2011.04.012.

29. Tanalp J, Karapinar-Kazandag M, Dölekoğlu Semanur, Kayahan MB. Comparison of the Radiopacities of Different Root-End Filling and Repair Materials. 2013;594950:4. DOI: $\underline{10.1155 / 2013 / 594950}$ 